\title{
Rape sentencing study: A review of statutory sentencing provisions for rape, defilement, and sexual assault in East, Central, and Southern Africa
}

Jill Thompson

Felly Nkweto Simmonds

Follow this and additional works at: https://knowledgecommons.popcouncil.org/departments_sbsr-rh

Part of the Domestic and Intimate Partner Violence Commons, and the International Public Health Commons

How does access to this work benefit you? Let us know!

\section{Recommended Citation}

Thompson, Jill and Felly Nkweto Simmonds. 2012. "Rape sentencing study: A review of statutory sentencing provisions for rape, defilement, and sexual assault in East, Central, and Southern Africa." Lusaka: Population Council. 


\section{RAPE SENTENCING STUDY}

STATUTORY SENTENCING PROVISIONS FOR RAPE,

DEFILEMENT, AND SEXUAL ASSAULT IN EAST, CENTRAL, AND SOUTHERN AFRICA

JILL THOMPSON FELLY NKEWTO SIMMONDS 

RAPE SENTENCING STUDY

\section{A REVIEW OF STATUTORY SENTENCING PROVISIONS FOR RAPE, DEFILEMENT, AND SEXUAL ASSAULT IN EAST, CENTRAL, AND SOUTHERN AFRICA}

JILL THOMPSON

FELLY NKEWTO SIMMONDS

POPULATION COUNCIL 


\section{(2) Population Council}

The Population Council confronts critical health and development issues-from stopping the spread of HIV to improving reproductive health and ensuring that young people lead full and productive lives. Through biomedical, social science, and public health research in 50 countries, we work with our partners to deliver solutions that lead to more effective policies, programs, and technologies that improve lives around the world. Established in 1952 and headquartered in New York, the Council is a nongovernmental, nonprofit organization governed by an international board of trustees.

Population Council

Zambia Office

Street Address:

Plot \#3670 No. 4 Mwaleshi Road

Olympic Park

Lusaka

Zambia

10101

Main Tel: +206 211295925

Fax: +206 211295925

Mailing Address:

Private Bag Rw 319X

Lusaka

Zambia

www.popcouncil.org

Suggested citation: Jill Thompson, Felly Nkewto Simmonds. 2012. Rape Sentencing Study: A Review of Statutory Sentencing Provisions for Rape, Defilement, and Sexual Assault in East, Central, and Southern Africa. Lusaka: Population Council.

(C) 2012 The Population Council, Inc. 


\section{TABLE OF CONTENTS}

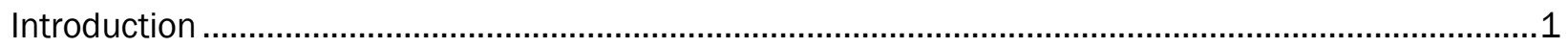

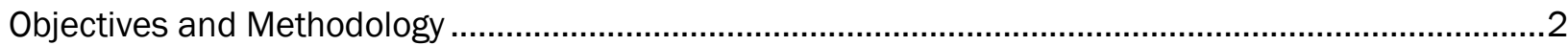

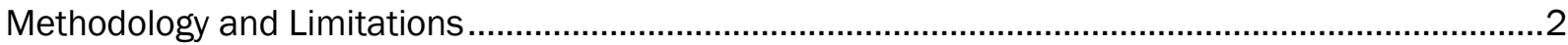

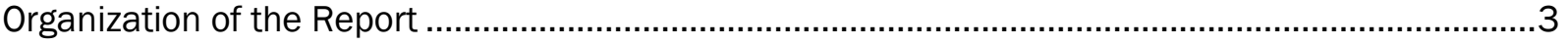

Background on Legal Systems and Sentencing Procedures...............................................................

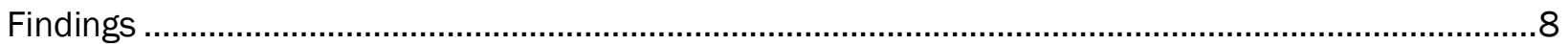

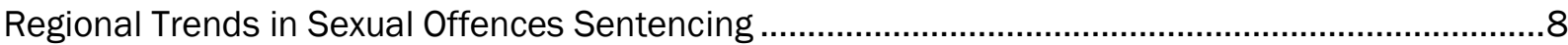

Comparison of Minimum Sentencing Approaches ….................................................................. 11

Critique of Sentencing Reforms Based on Sentencing Literature ...................................................... 15

Conclusion and Questions for Further Research ........................................................................... 18

ANNEX A: Summary of Current Sentences for Sexual Offences in Selected African Countries (2011) 


\section{INTRODUCTION}

In the past ten to twelve years, several countries in East, Central and Southern Africa have responded to the problem of violence against women and children by amending outdated criminal laws relating to rape and other forms of sexual and gender-based violence. Legislative reforms have ranged from minor changes to existing penal code provisions, to major overhauls of sexual offences law. Changes have included redefining and/or adding new offences; making sexual offences gender neutral; putting in place evidentiary and procedural protections for victims ${ }^{1}$; and increasing penalties for sexual crimes.

As part of the reform process, several countries in the region have enacted mandatory minimum sentences for sexual offences such as rape and "defilement." 2 These have generally emerged in response to public outcry over high rates of sexual violence - particularly against children, and the widespread perception among the public and some lawmakers that perpetrators were not being adequately punished for these crimes. Proponents argued that high mandatory sentences would have a deterrent effect on sexual violence, and that victims would be more likely to report if they believed that perpetrators would be sent to jail. ${ }^{3}$ Others argued that statutory minimums would ensure appropriate retribution and lead to greater consistency in sentencing. ${ }^{4} \mathrm{~A}$ further rationale was found in the HIV epidemic - high sentences were viewed by many as necessary to curb the spread of HIV to women and children from sexual assault. 


\section{OBJECTIVES AND METHODOLOGY}

This legislative review is Part I of a two-part desk review on sentencing of sexual offences and minimum sentences in the African and international context. The purpose of the review is to:

1) Document the sentencing reforms made in selected countries in the East, Central and Southern African region since 1998;

2) Identify the countries that have enacted minimum sentences and/or sentencing guidelines for sexual offences such as rape, defilement, and sexual assault; and

3) Consider the different approaches adopted by various sentencing schemes.

This review (Part I) should be read in conjunction with Part II of the Rape Sentencing Study, a review of peer reviewed literature on the topic of minimum sentences, with a particular focus on minimum sentences and sentencing guidelines in sexual offences cases. ${ }^{5}$

\section{Methodology and Limitations}

The following report is based on a desk review of sexual offences laws and sentencing statutes in twelve countries: Botswana, Ethiopia, Kenya, Lesotho, Namibia, Malawi, Rwanda, South Africa, Tanzania, Uganda, Zambia and Zimbabwe. For each country, the relevant criminal laws and specialized statutes were identified and reviewed. In some countries, this was limited to the Penal Code and relevant amendments. In others, this included specialized sexual offences or child protection legislation, and in two cases, specialized minimum sentencing acts.

The review was limited to legislation that was accessible online or obtained from personal sources. While every attempt was made to identify and obtain relevant statutes, it is possible that the review may not reflect all relevant laws, current amendments or recent developments. Except with regard to South Africa and Namibia, for which some analysis of sentencing laws was available, the review is also limited to sentencing provisions contained in legislation. Ideally, a comprehensive review would include a review of reported case law on rape sentencing, as well as identification and analysis of any judicial instructions, policies, and/or sentencing guidelines put in place since the introduction of sentencing reforms. Due to time and budget constraintst, however, such research was beyond the scope of this study.

The survey focuses on three sexual offences -- rape, defilement, and sexual or indecent assault, and the penalties available for these crimes. Although the criminal law in most of the selected African countries is derived from English common law, or a hybrid of Roman-Dutch and English law, 
recent reforms have resulted in widely varying definitions of these offences, as well as the addition of new offences. For example, conduct that was previously defined as "indecent assault," may now be defined as "rape" in some countries. ${ }^{6}$ Countries may also have refined the way they criminalize sexual acts with children or youth, distinguishing between consensual and non-consensual conduct, rather than treating all such conduct as "defilement" and/or "indecent assault." 7 The reader is therefore cautioned to look carefully at how the offences are defined in the different jurisdictions before making direct comparisons in terms of available penalties.

A matrix summarizing the sexual offences legislation and sentencing scheme adopted by each country is included in this survey for ease of reference. See ANNEX A.

\section{Organization of the Report}

The legislative review begins with a brief look at the legal systems and sentencing procedures followed in the various countries studied (Section III). This is followed by a summary of key findings and regional trends, including a comparison of different sentencing approaches (Section IV). In Section V, the various minimum sentencing regimes identifed in the law review are briefly analyzed in light of the minimum sentencing literature. Part VI concludes by identifying issues for further research. 


\section{BACKGROUND ON LEGAL SYSTEMS AND SENTENCING PROCEDURES}

In most of the countries reviewed for this study, the legal framework consists of the Constitution, legislative enactments and common law. Other sources of law may include African customary law, Islamic or Sharia law, and international human rights principles as embodied in legislation and the countries' respective Constitutions.

Half of the twelve countries reviewed -- Botswana, Malawi, Kenya, Tanzania, Uganda and Zambia -are common law countries, modelled after the English legal system. Although most criminal offences have been codified in a Penal Code, the interpretation and application of the law is governed by common law (judicial precedent) based largely on English law. In addition, as most of the penal code provisions in these countries were "inherited" from England during the period of colonial rule, the law and procedure for rape and other "Offences Against Morality" have remained almost identical across the six countries until quite recently.

The court system in Botswana, Malawi, Kenya, Tanzania, Uganda and Zambia consists of the High Court and Subordinate or "magistrates" courts. ${ }^{8}$ Technically, the High Court may exercise jurisdiction over any criminal matter; however in practice the vast majority of criminal matters (including most felonies) are adjudicated at the subordinate court level. The High Court has exclusive jurisdiction over the most serious offences (such as murder and capital offences), and also has jurisdiction over appeals. Jurisdiction over criminal matters within the Subordinate Courts depends on the penalty that can be imposed at various tiers (i.e. district court, regional court, chief magistrate). Trial courts are permitted to pass sentences within the limits of their jurisdiction. However, if the offence carries a penalty that exceeds the court's jurisdiction, magistrates must refer the case to a higher court for sentencing upon conviction. This is known as a "split procedure." Magistrates can also refer other cases to the High Court if they feel the case justifies a higher penalty than they have jurisdiction to impose.

Sentencing in criminal matters is largely a matter of judicial discretion, except where a minimum sentence is prescribed by statute. In the case of sexual offences, four of the six common law countries - Botswana, Kenya, Tanzania and Zambia -- have enacted minimum sentences for selected sexual offences, including rape. In Malawi and Uganda, only maximum penalties are statutorily prescribed, but these include the death penalty and life imprisonment. It does not appear from the research that any of the six countries with "English" systems have issued or enacted sentencing 
guidelines for sexual offences outside the sentencing ranges imposed by statute, although some statutes specify higher minimums for certain circumstances or types of cases. In Kenya, for example, the minimum sentence depends primarily on the age of the victim, and is also higher for "gang rape" or abuse by persons in positions of trust or authority. In Botswana, HIV infection increases the minimum sentence by five years.

In the absence of statutory or non-statutory guidelines, courts generally rely on traditional methods of sentencing. In general, this means that the courts may receive evidence of aggravating and mitigating factors, and take these into account in sentencing, subject to the minimum sentences prescribed. These factors are not generally articulated in statute or case law, leaving substantial discretion to the court. ${ }^{9}$ In some countries, legal reforms have strengthened the role of the victim in sentencing. In Kenya, for example, the court may hear evidence from the complainant about the impact of sexual assault and extent of harm suffered for purposes of imposing an appropriate sentence. ${ }^{10}$ This, according to one author, constitutes a "major leap forward" in the way the Kenyan legal system views victims of sexual offences. ${ }^{11}$

Sentences imposed by the lower and high courts in common law countries are subject to appellate review. In theory, the appeals court has very limited grounds to interfere with the sentencing of the trial court, for example -- where the sentence is illegal, capricious, based on wrong principles, or so harsh and excessive as to be unjust. ${ }^{12}$ Implementation of these principles vary, however, with some commentators arguing that the higher courts merely substitute their own discretion for that of the lower courts, without substantial justification or guidance for future sentencing. ${ }^{13}$

The legal systems of South Africa, Namibia, Lesotho and Zimbabwe are "hybrid" systems, containing elements of Roman-Dutch (civil law) and English (common law) systems, as well as African customary law. Historically, legislation has not been the primary source of law, although this is changing over time. In keeping with trends elsewhere, the laws in these countries have been increasingly codified, particularly with respect to sexual offences and other complex crimes In South Africa, Namibia, and Zimbabwe the "common law" refers to South African common law that is primarily Roman-Dutch (not English). However, statutes (such as the Sexual Offences Act of 2007) are often based on the English model and may have more in common with English common law countries than South African common law.

South Africa, Lesotho, and Namibia do not have a criminal code. Most criminal offences are defined in terms of common law, based on the Roman Dutch legal tradition. There are some statutory offences, however, including those contained in specialized sexual offences and child protection 
legislation. In Zimbabwe, sexual offences have been revised and codified in the context of a comprehensive Criminal Code, replacing previous specialized legislation on sexual offences.

Like the "English" common law countries, the jucicial systems of South Africa, Lesotho, Namibia and Zimbabwe are comprised of higher and lower courts. By far the vast majority of criminal cases are adjudicated at the Magistrate Courts level. According to statute, district and regional courts generally have jurisdiction over criminal offences except for murder, treason, capital offences, and certain statutory offences (such as drug trafficking and/or serious economic crimes), which are left to the High Court. Jurisdiction among the lower courts is determined by statute and is based on the level of punishment. For example, in Zimbabwe, a regional magistrate can normally impose a sentence of up to 10 years imprisonment, whereas senior and provincial magistrates are limited to 4 and 5 -year sentences, respectively. For sexual offences, however, special jurisdiction has been granted to the regional courts, who may now impose higher sentences. In South Africa, the sentencing jurisdiction of the regional courts -- until recently - was 15 years. ${ }^{14}$ This was expanded in 2007 to allow regional courts to sentence certain scheduled offences for which a life sentence could be imposed under the Minimum Sentencing Act, including aggravated and child rape. Other offences carrying penalties that exceed the jurisdiction of the magistrates court, must still be referred to the regional or High Court for sentencing. Sentences may also be subject to appellate review.

In addition to the district courts, South Africa, Zimbabwe and Namibia have established some specialized sexual offences courts nationally to handle sexual violence cases. These courts have institutionalised "victim friendly" procedures and may have specially-trained prosecutors. Sexual offence courts do not have exclusive jurisdiction, however. Due to sheer volume, many more cases involving sexual offences are handled by regular magistrate's courts, and sexual offences courts increasingly handle other types of matters as well.

As in the "English" common law countries, sentencing in criminal matters is largely a matter of discretion by the court. In statutory provisions, criminal sentences are usually stated in terms of a statutory maximum or "cap," and only occasionally include a minimum sentence. A person liable to a sentence of imprisonment for any period may be sentenced to imprisonment for any shorter period, and a person liable to a fine of any amount may be sentenced to a fine of any lesser amount. The court may also impose a suspended sentence. Under common law, the court may take into account the circumstances of the criminal, the crime, and the interests of society in determining the sentence imposed. The court also has "inherent discretion" to impose any allowable sentence for an offence where the statute does not prescribe a specific penalty. 
Since 1997, three of the four "hybrid" countries --South Africa, Namibia, and Lesotho -- have established statutory minimums for certain serious crimes, including rape and sexual assaults. ${ }^{15}$ What is surprising about these minimums is that they are largely discretionary. Indeed, in South Africa and Namibia, courts are required to deviate from the statute and impose a lesser sentence where they find "substantial and compelling circumstances," or where the minimum sentence would be "unjust." ${ }^{16}$ Since these terms are not defined in the statute, and in the absence of other guidelines, it appears that courts continue to determine sentences in largely the same way that they always have by weighing all the traditional mitigating and aggravating factors, and tailoring the sentence to the individual case. ${ }^{17}$ With respect to sexual offences, only South Africa has amended its sentencing scheme to clarify what factors may not be considered "substantial and compelling" for purposes of mitigation. ${ }^{18}$

Rwanda and Ethiopia are the two countries in the study with legal traditions and systems differing from those of the others discussed. Until recently, Rwanda had a civil law system inherited from the Belgian colonial system. During the colonial period, all legislation was made by Belgian authorities and was based on the civil and criminal codes of the then Belgian Congo. Rwanda is now in the process of moving from a purely civil law legal system to a hybrid of civil and common law, influenced by international human rights principles. This has lead to the reform of the penal code, and the development of new laws and specialized legislation such as the Prevention and Prosecution of Gender-Based Violence Act. Post-genocide, Rwanda has also revised its laws on criminal procedure, courts and evidence. Ethiopia's legal system is also moving from a civil law system to a hybrid of civil and common law. From 1957 to 2005 Ethiopia's criminal law was codified in a Penal Code based on the Penal Code of Switzerland. In 2005, Ethiopia established a new Criminal Code, including many reforms based on international obligations and human rights principles. Both Rwanda and Ethiopia have a system of higher and lower courts. Ethiopia is unique, however, in that it has a dual judicial system with parallel court structures at the federal and state level. Both systems have criminal and civil jurisdiction; however it appears that sexual offences are normally heard in the state courts. 


\section{FINDINGS}

\section{Regional Trends in Sexual Offences Sentencing}

Of the twelve countries examined in the legislative review, eleven have enacted new legislation or amendments to existing law on sexual offences since 1998. For some, these have been sweeping changes that have significantly changed the substantive and procedural law on sexual offences in their respective countries. Namibia and South Africa are two examples, where even the notion of "consent" has been revisited and refined. ${ }^{19}$ For others, such as Zambia and Botswana, the reforms have been relatively modest - consisting primarily of increased penalties for offences, increasing the relevant age for offences against children, and/or making sexual offences gender-neutral. In the case of Zimbabwe, reforms to sexual offences law were made initially in special legislation ${ }^{20}$, which was later repealed and reformulated in the subsequent codification of Zimbabwe's criminal law. ${ }^{21}$ Similarly, Ethiopia undertook to reform sexual offences law in the course of enacting a new criminal code. $^{22}$ In Rwanda, strict laws on violence against children were enacted in 2001, followed by specialized gender-based violence act in $2009 .^{23}$

Five of the twelve countries in the study - Kenya, Lesotho, Namibia, South Africa, and Tanzania have enacted a specialized sexual offences act. ${ }^{24}$ Typically this type of legislation includes: a broad definition of rape to include any form of non-consensual penetration of a male or female, regardless of age; an abolition of the cautionary rule for sexual offenses; procedural and evidentiary protections for witnesses; a provision making it an offence to deliberately transmit HIV; and, in the case of Namibia, Lesotho, South Africa, Zimbabwe and Rwanda, a provision recognizing the offence of rape in marriage. ${ }^{25}$

Of the five countries with specialized sexual offence legislation, four -Kenya, Lesotho, Tanzania and Namibia -- prescribe minimum sentences for certain sexual offences in the Act itself. In South Africa, minimum sentences are determined according to the Criminal Law Amendment Act of 1997, which prescribes minimum sentences for "serious offences," including, but not limited to, murder, rape and child rape. Like Lesotho and Namibia, however, South African law permits the court to deviate from minimum sentences where there are "substantial and compelling" circumstances. ${ }^{26}$ Minimums are also not applicable to juvenile offenders. All five countries with specialized legislation also include provisions in their legislation requiring higher sentences in certain cases, such as those involving repeat offenders and/or aggravating circumstances. Depending on the country, aggravating circumstances may include such factors as HIV status of perpetrator, serious injury to the victim, infection of victim with HIV or other serious diseases, multiple perpetrators, use of a 
weapon, abuse of a position of authority or trust, etc., or may be based on the age or vulnerability of the victim, the relationship of the perpetrator to the victim, or the nature of the sexual act.

Although not a sexual offences statute per se, Rwanda's 2009 Gender-Based Violence statute also prescribes certain penalties for violence against women. Among these, it provides a minimum sentence for rape, as well as aggravated penalties where the rape results in the illness, injury or death of the victim. Earlier legislation relating to violence against children also prescribes high minimum sentences for child rape, including life sentences for cases with aggravating circumstances. ${ }^{27}$

In addition to those with specialized legislation, other countries in the region have also made changes with respect to sentencing of sexual offences. In 1998, Botswana was one of the first countries in the region to increase penalties for certain sexual offences and include a statutory minimum for rape and defilement in its penal code. ${ }^{28}$ It was also one of the first countries to redefine the offence of rape to include other forms of sexual penetration and to make the offence gender neutral. ${ }^{29}$ In 2005, Zambia enacted a number of amendments to its penal code sections on sexual exploitation of children, which included, among other changes, the establishment of minimum sentences for defilement (sexual intercourse with a girl under 16) and indecent assault. ${ }^{30}$ In 2011, Zambia enacted a further amendment, establishing a minimum sentence for rape and attempted rape. ${ }^{31}$ In its sexual offences act and subsequent Criminal Code, Zimbabwe made a number of significant changes to the common law, added new offences, and increased the penalties available for certain sexual offences. It did not establish minimum sentences in the Criminal Code, however, and does not appear to have other minimum sentencing legislation in place, as in South Africa. In 2005, Ethiopia enacted a new Criminal Code, containing minimum sentences for rape as well as sexual acts with minors, with higher penalties prescribed for aggravating circumstances.

Despite the trend toward reform, two of the countries reviewed -- Malawi and Uganda -- do not appear to have substantially amended their laws on sexual offences and retain most of the original common law provisions from their original Penal Codes of 1930 and $1950 .^{32}$ Both countries have had proposed amendment bills and/or special sexual offences legislation pending before their Parliaments for years, but it does not appear from the desk review that these have yet been enacted. One exception is a 2007 amendment to the law on defilement in Uganda. This measure made defilement a gender-neutral offence, increased the age of consent to 18, and added a new offence of “aggravated defilement." It also established a penalty of up to life imprisonment for defilement, and up to death for aggravated defilement, but did not prescribe a minimum sentence for either offence. $^{33}$ 
Table 1: Sentencing reforms in selected African Countries

\begin{tabular}{|c|c|c|c|c|c|c|c|c|}
\hline & $\begin{array}{l}\text { Sexual } \\
\text { Offences Act } \\
\text { or } \\
\text { equivalent }\end{array}$ & Amendments & $\begin{array}{l}\text { Increased } \\
\text { Penalties for } \\
\text { Sexual } \\
\text { Offences }\end{array}$ & $\begin{array}{l}\text { Minimum } \\
\text { Sentence for } \\
\text { Rape (or } \\
\text { equivalent) }\end{array}$ & $\begin{array}{l}\text { Minimum } \\
\text { Sentence for } \\
\text { Defilement/ } \\
\text { child rape }\end{array}$ & $\begin{array}{l}\text { Minimum } \\
\text { Sentence for } \\
\text { Sexual Assault }\end{array}$ & $\begin{array}{l}\text { Discretion to } \\
\text { deviate from } \\
\text { Min Sentences }\end{array}$ & $\begin{array}{l}\text { Aggravating } \\
\text { Factors } \\
\text { (statutory) }\end{array}$ \\
\hline Botswana & No & 1998 & Yes & Yes & Yes & No & $?$ & Yes \\
\hline Ethiopia & No & $\begin{array}{l}\text { Revised } \\
\text { Criminal Code } \\
2005\end{array}$ & ? & Yes & Yes & Yes & $?$ & Yes \\
\hline Lesotho & Yes, 2003 & & Yes & Yes & Yes & Yes & Yes & Yes \\
\hline Kenya & $\begin{array}{l}\text { Yes, } 2006 \\
(\text { rev 2010) }\end{array}$ & & Yes & Yes & Yes & Yes & $?$ & Yes \\
\hline Malawi & No & ? & $?$ & No & No & No & N/A & No \\
\hline Namibia & Yes, 2000 & & Yes & Yes & See rape & See rape & Yes & Yes \\
\hline Rwanda & $\begin{array}{l}\text { Yes, } 2009 \\
\text { (Gender- } \\
\text { Based } \\
\text { Violence) }\end{array}$ & & Yes & Yes & Yes* & Yes & ? & Yes \\
\hline $\begin{array}{l}\text { South } \\
\text { Africa }\end{array}$ & Yes, 2007 & & Yes* & Yes* & See rape & Some & Yes & Yes \\
\hline Tanzania & Yes, 1998 & 1998 & Yes & Yes & See rape & Yes & $\begin{array}{l}\text { First offenders } \\
\text { only* }\end{array}$ & No \\
\hline Uganda & No & 2007 & $\begin{array}{l}\text { Yes, for } \\
\text { defilement }\end{array}$ & No & No & No & N/A & $\begin{array}{l}\text { Yes, for } \\
\text { defilement }\end{array}$ \\
\hline Zambia & No & 2005, 2011 & Yes & Yes & Yes & Yes & $?$ & No \\
\hline Zimbabwe & $\begin{array}{l}(2001, \\
\text { Repealed) }\end{array}$ & $\begin{array}{l}\text { Codified } \\
\text { Criminal Law } \\
2006\end{array}$ & Yes & No & No & No & N/A & Yes \\
\hline
\end{tabular}

* Contained in other statute.

Among the other trends and reforms observed, a few warrant particular mention. First is the inclusion of new offences and/or higher sentences based on a criminal offender's HIV status, and/or the transmission of HIV or other serious diseases to victims of sexual assault. In at least eight of the countries reviewed for this study, HIV infection or transmission is in some way, explicitly or otherwise, treated as an aggravating factor in sentencing. The HIV epidemic has also lead countries in the region to enact new offences to criminalize certain related behaviors: for example, in Lesotho, non-disclosure of HIV infection to a sexual partner, is considered - and punished - as an unlawful sexual act. In Zambia, it is a serious offence, comparable to defilement, to prescribe defilement to cure a disease. Several countries, including Kenya and Zimbabwe, have made 
it a crime to deliberately or recklessly transmit HIV. Likewise, several countries, including South Africa, Kenya, and Botswana, have enacted special (and controversial) provisions for mandatory testing and disclosure of an accused's HIV status, for purposes of prosecution and sentencing.

A second trend noted is the frequent inclusion of sentencing provisions recognizing abuse of power or trust as an aggravating factor in sentencing, particularly with regard to defilement, sexual assault and/or child rape. Examples include Namibia, which imposes a higher minimum sentence for rape if the victim is under 18 and the offender is in a position of trust vis a vis the victim. The relative power of the offender and/or the relationship of the offender and victim is also recognized as an aggravating factor in the laws of Uganda, Zimbabwe, Rwanda, and Ethiopia. In some cases these positions or relationships are specifically delineated (i.e. teacher, religious leader, law enforcement officer, guardian, parent) and in others, left open to interpretation.

Finally, two less common but important reforms were also observed in relation to sentencing of sexual offences. First, it was noted that some statutes now explicitly recognize mental harm or injury to the victim as a factor in sentencing, in addition to the more common physical injury or illness. Examples include Ethiopia, Lesotho, Rwanda and Zimbabwe. Second, at least two countries Uganda and Tanzania - mandate payment of compensation to victims of defilement and sexual offences, respectively. Others, such as Rwanda, allow victims to request damages and/or payment of medical expenses as part of the sentence imposed.

\section{Comparison of Minimum Sentencing Approaches}

As shown in Table 1, the majority of African countries in the study have enacted minimum sentences for rape and sexual assault in addition to other reforms. Several have also created minimums for "defilement" or alternatively, redefined the offence so that the minimum sentences for rape or sexual assault apply in cases of non-consensual sexual acts involving minors, and all cases involving children under a certain age.

Despite this clear trend, the approach that different countries have taken to minimum sentences varies considerably. In Tanzania and Zambia, for example, law-makers have simply imposed high mandatory minimum sentences for all cases of rape or defilement regardless of the circumstances of the case. In Zambia, the minimum is 15 years for rape or defilement, 5-14 years for attempt. ${ }^{34}$ In Tanzania, the minimum is even higher - 30 years for rape/defilement and attempted rape In these countries, the law does not distinguish between consensual or non-consensual sex if the victim is under a certain age. Nor do the statutes distinguish between "aggravated" cases and those that are not. While simple to administer, this approach does not allow the courts any room to impose a 
lower sentence based on the specific circumstances of the case. Thus, it appears from the statute that a case of consensual sexual intercourse involving a nineteen year old with his fifteen year old girlfriend would carry the same minimum sentence as the gang rape of a seven year old girl. ${ }^{35}$

In other countries, lawmakers have enacted a somewhat more detailed sentencing scheme for sexual offences based on various factors. In Botswana, for example, the minimum sentence for rape or defilement is ten years up to life imprisonment. ${ }^{36}$ The minimum increases to fifteen years if the offence is violent or causes injury, and fifteen to twenty, if the perpetrator is infected with HIV. Attempted rape or defilement carries a penalty of not less than 5 years imprisonment to life. In Kenya, rape of an adult carries a minimum sentence of 10 years, and "gang rape" raises the minimum to fifteen. The minimum sentence for defilement is determined according to the age of the child, rather than specific aggravating circumstances for under 12 , the minimum is life; for children 12-15, a minimum of 20 years; for children 16-18, a minimum of 15 , regardless of other circumstances. $^{37}$ Deliberately or recklessly infecting a victim with HIV is not an aggravating factor in Kenya but a separate offence. ${ }^{38}$

Ethiopia's sentencing scheme is one of the more complex. Under the Revised Criminal Code, the minimum sentence for rape is relatively lower - five years - except in cases involving grave physical or mental injury or death of the victim, which carries a life sentence. ${ }^{39}$ Aggravating factors for rape are specifically delineated in the sentencing scheme, but increase the maximum sentence available rather than the minimum. These factors include: age of the victim, relationship of the victim to the perpetrator/abuse of power or trust; physical or mental disability, multiple perpetrators, and acts of particular cruelty or violence. Courts presumably have discretion to impose any sentence within the statutory range, with higher penalties encouraged for cases with aggravating circumstances.

Like Kenya, Ethiopia bases the minimum (and maximum) sentences for defilement/sexual abuse ("sexual outrages against minors or infants") on the age of the child. Consensual or non-consensual sexual intercourse with a girl under 13 carries a minimum penalty of 13 years; the same act with a girl age 13-18 carries a minimum sentence of 3 years. Ethiopia also sets a higher minimum for child sexual abuse when perpetrated by a person in a position of trust or authority, or on whom the victim is dependent. This includes, for example, teachers, domestic employers, and institutional care givers. Ethiopia recognizes rape and sexual abuse of boys, but oddly, sets out a lower penalty when that abuse is committed by a person of the opposite sex. The statute also calls for higher sentences in cases where the victim becomes pregnant, contracts a sexually transmitted disease, or is "driven to suicide" as a result of the rape or sexual abuse. ${ }^{40}$ 
Other countries have taken a different approach. Namibia, Lesotho and South Africa have also established relatively high minimum sentences for rape and related offences. However, each provides different minimums for different types of cases, depending on the nature of the assault, the age of the victim, and whether the perpetrator is a first or repeat offender. In South Africa, for example, the Criminal Law Amendment Act of 1997 prescribes minimum sentences for rape, child rape (under 16) and sexual assault of a child with bodily harm. The law makes two principal distinctions: Most adult rapes are Schedule II Part 3 cases, for which the minimum sentence for rape is ten years, or fifteen to twenty for repeat offenders. Child rape (defined as rape of girls under the age of 16) and other aggravated cases constitute Part 1 offences and carry a minimum sentence of life imprisonment. Aggravated cases include multiple rapes, gang rapes, rapes causing grievous bodily harm, rapes of physically or mentally disabled victims, and cases where the perpetrator knows he or she is HIV+ at the time the rape is committed.

Sentencing in Namibia is similarly prescribed, although the minimum sentences are lower, particularly for aggravated cases by first offenders. Under the Combating of Rape Act, a first time offender will face a mandatory jail term of anywhere from five to fifteen years, depending on the case, compared to a possible life sentence in South Africa. Repeat offenders face a minimum of ten to forty-five years. Namibia also prescribes harsher minimum sentences in cases with specific factors present. For example, the penalty for rape of a child under age 13, gang rape, or rape with the use of a firearm is not less than fifteen years for a first offender. Likewise, an offender who is infected with a serious sexually transmitted disease and is aware of it when he or she rapes someone will face a higher minimum sentence. For a first time offender, this draws a mandatory fifteen year sentence (compared to life in South Africa).

Another important difference in approach is the inclusion of language in the statutes of South Africa, Namibia and Lesotho allowing courts to deviate from the statutory minimums where "substantial and compelling" or "extenuating" circumstances so require. While somewhat constrained by statute and legislative intent, judges in South Africa, Namibia, and Lesotho retain wide discretion to impose less severe sentences than prescribed by statute where "substantial and compelling" circumstances justify a lighter sentence. ${ }^{41}$ As a result of this provision, minimum sentences are not mandatory in the same way as other countries in the study, and judges regularly impose less than the "minimum" sentence. ${ }^{42}$

Of the three countries that have not enacted statutory minimums for sexual offences, Zimbabwe is the only one that has substantially reformed its sexual offences laws. Reforms have included the introduction of new offences, spousal rape, victim-friendly court procedures, and heightened 
penalties for sexual offences against both males and females (up to life imprisonment for rape and aggravated indecent assault). ${ }^{43}$ In lieu of minimum sentences, Zimbabwe's Criminal Code section 65 (2) delineates specific factors to be taken into account in sentencing for rape. These are similar in many respects to those addressed in the minimum sentences of other countries. The difference is that specific sentences are not prescribed according to these factors -- application is left to the discretion of the court. Sentencing factors in Zimbabwe include:

- the age of the person raped;

- the degree of force or violence used in the rape;

- the extent of physical and psychological injury inflicted upon the person raped;

- the number of persons who took part in the rape;

- the age of the person who committed the rape;

- whether or not any weapon was used in the commission of the rape;

- whether the person committing the rape was related to the person raped in any of the degrees mentioned in subsection (2) of section seventy-five (incest);

- whether the person committing the rape was the parent or guardian of, or in a position of authority over, the person raped; and

- whether the person committing the rape was infected with a sexually transmitted disease at the time of the rape.

Finally, it is important to note the ways in which other changes to the law of sexual offences have had an impact on sentencing, particularly the redefinition of rape and introduction of new offences. For example, in Botswana, Namibia, Kenya, and South Africa, many forms of sexual assault not covered by rape under common law are now statutorily defined as rape and subject to the same minimum sentences. ${ }^{44}$ An example is penetrative anal and/or oral sex involving both male and female victims. Another difference is in the way minimum sentences are applied to sexual offences involving children. In Namibia and South Africa, consensual sex with a child over the age of twelve is not defined as rape, and does not carry a minimum sentence. In contrast, unlawful sex with a child over twelve constitutes "rape" or "defilement" in Kenya, Botswana, Tanzania, and Zambia, regardless of consent. In these countries, minimum sentences for defilement range from ten years to life. 


\section{CRITIQUE OF SENTENCING REFORMS BASED ON SENTENCING LITERATURE}

Apart from South Africa, there appears to be very little information available concerning the application or efficacy of minimum sentencing laws in Africa in the peer-reviewed journals. With so little literature available, it is necessarily difficult to draw conclusions about the implementation or effectiveness of the various sentencing schemes discussed above. Despite these limitations, the international literature does provide some general insights into the strengths and weaknesses of

minimum sentences and different sentencing regimes, which are relevant in the African context. ${ }^{45}$

Most importantly, the international literature is almost universally critical of sentencing regimes which provide high minimum sentences with little or no variance for different circumstances - such as found in Zambia or Tanzania, as well as those - such as in South Africa - in which judges retain almost unfettered discretion. Those systems in between - i.e. those that prescribe different minimums for certain types of cases based on specific aggravating factors - fare somewhat better in the review. However, even these are considered "blunt instruments" in the absence of detailed sentencing guidelines. ${ }^{46}$

According to the literature, the principle weakness of the first approach is that the minimum sentences treat all cases of a given offence the same. Technically, the court can still sentence up from the minimum if it finds aggravating circumstances, but many courts are reluctant to do so where the minimum is already high (i.e. 15 years to life). More importantly, there is a serious risk that a high minimum sentence will, in many cases, violate the principle of "proportionality," and may even be found unconstitutional. In addition to violating the rights of the offender, some commentators suggest that courts will be reluctant to convict at all if they are forced to impose a sentence they deem "unjust" under the circumstances. ${ }^{47}$

Commentators are equally critical of approaches that allow courts too much discretion to deviate from statutory minimums, at least in the absence of detailed sentencing guidelines. ${ }^{48}$ In South Africa, for example, the minimum sentencing regime (as interpreted by the courts) has reportedly led to greater inconsistency and unpredictability in sentencing than before the law was enacted. Given the frequency with which courts find "substantial and compelling circumstances," courts there, and in Namibia, are still perceived as "promoting leniency" in many cases, and have also been criticized for using inappropriate and irrelevant factors to reduce sentences far below the statutory minimums. 
This is particularly true in sexual offences cases, where sentences are highly dependent on the (sometimes biased) value judgements of the court.

Given these critiques, the sentencing approach most often recommended in the literature is a system of graduated sentencing based on aggravating circumstances, coupled with detailed sentencing guidelines to "structure" judicial discretion. Guidelines may be statutory or non-statutory, although most commentators prefer systems - like those in the US and UK - in which statutory directions (such as minimum sentences) are combined with detailed guidelines established by an independent sentencing council.

Under this kind of sentencing scheme, statutes may still provide a sentencing range, including a minimum and maximum sentence. Within this range, however, are several gradations for various factors and circumstances, reducing the risk of arbitrary and/or disproportionate results. Ideally, under this scheme, the minimum sentence for rape would be lower than that currently prescribed in many African countries (for example, five to ten years instead of 15 to 30), but would be treated as a base from which courts could not deviate except in the most exceptional cases. From this base, courts would be expected to apply the sentencing guidelines to increase the penalty in specific increments (or within a specific range) for each aggravating factor found, up to the maximum sentence allowed by law. Detailed guidelines would instruct the courts as to the type of aggravating and mitigating factors to be considered and the weight to be given different factors, as well as disallowing certain factors, as required. While complex, the benefit of such a system, according to the literature, is that it would preserve high sentences for sexual violence while promoting consistency and proportionality and limiting (but not eliminating) judicial discretion. ${ }^{49}$

At present, none of the countries reviewed for this study have implemented a detailed "guidelines" system to determine sentencing in sexual offences cases. However, some have incorporated certain elements, allowing for a greater range of sentences within a minimum sentencing scheme. In Namibia, for example, the statute prescribes a relatively low five year minimum for a first offence of rape, up to a minimum forty-five years for a repeat offence with aggravating circumstances. The statute also identifies at least eight specific aggravating factors for which the minimum is raised to ten or fifteen years for a first offence, higher for subsequent offences. This approach, incorporating criminal history and multiple aggravating factors, provides a greater range of sentencing options than many other statutes in the region, including the South African statute on which it was based. As discussed, the challenge in Namibia (as in South Africa) is that the "substantial and compelling clause" (as interpreted) allows too much discretion to deviate from the statutory scheme. Although 
some discretion may be necessary to prevent unjust results, the literature suggests that unfettered discretion may also lead to disparate and unjust outcomes.

Ethiopia and Zimbabwe have also enacted a type of statutory guideline, although not as detailed or nuanced as the recommended approach. Each also has certain weaknesses. In Zimbabwe, for example, the rape statute lists specific factors to be considered in sentencing, but does not prescribe any minimums or specific sentences for aggravated cases. This approach arguably leaves too much discretion in the hands of the court and may result in widely varying sentences for similar cases. Ethiopia, in contrast, has adopted a highly prescriptive approach. While it provides for a wide range of sentences for rape and defilement (five years to life) based on aggravating circumstances, it does not appear on its face to allow any deviation from the minimums imposed.

Another relevant critique noted in the literature, is the strain that minimum sentences can place on an already burdened criminal justice and correctional systems. In South Africa, for example, researchers found that minimum sentences had increased inefficiency and backlogs, "causing havoc" in the courts. They noted in particular the problem presented by dual procedures, in which cases were tried in lower courts, but referred to the high court for sentencing. ${ }^{50}$ In this study, most of the legal systems reviewed limit the sentencing jurisdiction of the lower courts, often below the minimum sentences prescribed by statute for rape and other offences. This means that many sexual offences cases will be tried by a lower court but sentenced by the high court, requiring a dual or split procedure. This suggests that countries already experiencing case backlogs are likely to experience even longer delays in finalizing cases, causing hardship to the victim and increasing the likelihood of withdrawals and/or acquittals. As in South Africa, offenders may also be less likely to plead guilty in the face of high minimum sentences, requiring more victims to endure a full trial.

The literature also suggests that high penalties for sexual offences, including minimum sentences, are unlikely to have a significant impact in Africa in the absence of other legal, institutional and societal reforms. While statutory minimums may result in higher penalties, there is no evidence that high sentences deter sexual violence or increase reporting or conviction rates, particularly where criminal justice systems are weak and under-resourced. What is needed is a comprehensive strategy to prevent sexual violence and protect victims, while building the capacity of courts and law enforcement to address these crimes. ${ }^{51}$ Higher penalties should also be accompanied by more indepth reform of sexual offences laws - to redefine rape and defilement, increase evidentiary protections, and institute victim friendly procedures. Several countries in the region, including South Africa, Kenya, Namibia, and others, have made significant advancements in this regard 


\section{CONCLUSION AND QUESTIONS FOR FURTHER RESEARCH}

The sentencing framework for sexual offences has changed dramatically in the past ten to twelve years across East, Central and Southern Africa. In addition to other reforms, at least nine countries in the region have enacted legislation creating minimum sentences where they previously did not exist.

Despite this common trend, the sentences available for sexual offences under these sentencing schemes vary considerably from country to country, ranging from no minimum to the death penalty for similar offences. Most laws in the region recognize aggravating circumstances in the context of rape or sexual violence, but these factors also vary in type and number. Finally, one finds very different approaches to judicial discretion in the context of sexual crimes. In most of the countries studied, judicial discretion under common law has been significantly curtailed. In others, courts continue to exercise wide discretion and regularly impose sentences lower than those statutorily prescribed.

A significant challenge at this stage is the lack of research or data on the implementation and efficacy of minimum sentences in Africa, as well as the comparative strengths and weaknesses of different approaches. Further research is needed to determine how and to what extent different countries (and courts) are applying minimum sentences, and the impact of sentencing reforms. These are not questions that can be answered in a desk review - they require field research and access to qualitative and quantitative data.

From this initial review of statutory provisions and the concurrent literature review, a number of key issues emerge as potential questions for further research. Among these:

1. What accounts for the substantial differences between African countries in the minimum sentences prescribed or the approach taken to the question of sentencing?

2. Have minimum sentences achieved the stated objectives of increasing reporting, deterring offences, and improving consistency?

3. What are the strengths and weaknesses of different approaches to sentencing in the region? Are some more effective than others? If so, why? 
4. To what extent are courts implementing the statutory minimums and applying statutory guidelines? What are the average sentences being imposed for sexual offences, including specific types of aggravated cases?

5. To what extent are judges relying on other guidance outside the statutory scheme to structure their sentencing decisions? If so, what is the nature and source of this guidance and how is it being applied by the courts?

What has been the impact of minimum sentences on the prosecution and adjudication of sexual offences cases, conviction rates, length and type of sentence imposed, the experience of survivors, community perceptions and attitudes, and the criminal justice systems as a whole? Do judges, policy makers and victims believe that the penalties being imposed under minimum sentencing regimes are more or less proportional to the gravity of the crimes, or are they too high or too low? Do judges and prosecutors avoid prosecution (or conviction) if the statutory penalty seems too harsh for the circumstances of the case? Are justice systems coping with the changes in sentencing or are harsher penalties, particularly life sentences, delaying sentencing and "causing havoc" in the courts? Do victims feel their cases are being taken more seriously? Is the public satisfied? Are cases being withdrawn or unduly delayed because of minimum sentencing? And finally, what impact does sentencing have on secondary trauma and victims' experience of the criminal justice system? Have sentencing reforms increased or reduced "access to justice" for victims of sexual crimes. 


\section{ANNEX A: SUMMARY OF CURRENT SENTENCES FOR SEXUAL OFFENCES IN SELECTED AFRICAN COUNTRIES (2011)}

\begin{tabular}{|c|c|c|c|c|}
\hline & Rape & Defilement & Sexual or indecent Assault & Relevant Statute \\
\hline Botswana & $\begin{array}{l}\text { Min. } 10 \text { yrs to max. life; min. } \\
15 \text { yrs where use of violence } \\
\text { causes injury; min. } 20 \text { yrs. if } \\
\text { offender is HIV+ and aware; } \\
\text { attempt, min. } 5 \text { yrs to life. } \\
\text { Concurrent sentences not } \\
\text { permitted. } \\
\text { Note: Revised common law } \\
\text { definition, any penetration, } \\
\text { gender neutral. }\end{array}$ & $\begin{array}{l}\text { Min. } 10 \text { yrs to life; min } 20 \text { yrs } \\
\text { if offender is HIV+ and aware; } \\
\text { attempt up to } 14 \text { yrs (no min.) } \\
\text { Note: applies to any person } \\
\text { under } 16, \text { not spouse, w/ or } \\
\text { w/o consent }\end{array}$ & $\begin{array}{l}\text { Up to } 7 \text { yrs imprisonment with } \\
\text { or without corporal } \\
\text { punishment (no min.) } \\
\text { Note: applies to any person } \\
\text { (gender neutral). Assaults } \\
\text { involving penetration, now } \\
\text { treated as rape. } \\
\text { Note: consent not a defense if } \\
\text { victim under } 16 .\end{array}$ & $\begin{array}{l}\text { Penal Code (Ch. 8:01) as } \\
\text { amended by Penal Code } \\
\text { Amendment Act (No } 5 \text { of } \\
\text { 1998): } \\
\text { S 142: rape } \\
\text { S 146: sexual assault } \\
\text { S 147: defilement } \\
\text { S 164: sodomy } \\
\text { S 166: indecent assault of } \\
\text { boys under 14 } \\
\text { Available at: } \\
\text { www.elaws.gov.bw/default.ph } \\
\text { p?UID=602; } \\
\text { www.chr.up.ac.za/undp/dome } \\
\text { stic/docs/legislation 38.pdf }\end{array}$ \\
\hline
\end{tabular}




\begin{tabular}{|c|c|c|c|c|}
\hline & Rape & Defilement & Sexual or indecent Assault & Relevant Statute \\
\hline Ethiopia & $\begin{array}{l}\text { Min. } 5 \text { yrs to max } 15-20 \text { yrs, } \\
\text { depending on aggravating } \\
\text { factors; min. life imprisonment } \\
\text { where rape causes grave } \\
\text { physical or mental injury, or } \\
\text { death. } \\
\text { Aggravating factors include } \\
\text { age of victim (13-18), abuse of } \\
\text { power/relationship or } \\
\text { vulnerability, multiple } \\
\text { perpetrators, or cruelty. } \\
\text { Note: applies to sexual } \\
\text { intercourse with females only, } \\
\text { not spouse. }\end{array}$ & $\begin{array}{l}\text { Min. } 13 \text { yrs, up to } 25 \text { yrs. if } \\
\text { victim is girl under age 13; } \\
\text { Min. } 3 \text { yrs, for girl age 13-18; } \\
\text { Min } 5 \text { yrs if aggravating } \\
\text { circumstances; life where } \\
\text { causes grave bodily or mental } \\
\text { injury or death of victim. } \\
\text { Note: term "defilement" not } \\
\text { used. Applies to sexual } \\
\text { intercourse with female } \\
\text { minors only, w/ or w/o } \\
\text { consent if under 13; w/ } \\
\text { consent if over 13. (See rape } \\
\text { for w/o consent). Different } \\
\text { offence with lower penalty for } \\
\text { female perpetrators of sexual } \\
\text { offences against male minors. }\end{array}$ & $\begin{array}{l}\text { Ranges from min. } 3 \text { months to } \\
\text { min. } 5 \text { yrs depending on } \\
\text { seriousness of assault and } \\
\text { relationship of victim to } \\
\text { perpetrator (pupil, domestic } \\
\text { servant, ward, etc.) } \\
\\
\text { Note: Art. } 622-628 \text { apply to } \\
\text { offences against victim of } \\
\text { opposite sex only. See Art 629- } \\
631 \text { for same-sex "indecent } \\
\text { acts," w/ or w/o consent. } \\
\text { Aggravating circumstances: } \\
\text { coercion/force; age of victim; } \\
\text { relationship of victim to } \\
\text { perpetrator; cruelty; leads to } \\
\text { STI or suicide. }\end{array}$ & $\begin{array}{l}\text { Revised Criminal Code } 2004 \\
\text { (2005): } \\
\text { Art. 620: rape } \\
\text { Art 622: sexual outrages } \\
\text { accompanied by violence } \\
\text { Art 626: sexual outrages on } \\
\text { minors (13-18) } \\
\text { Art 627: sexual outrages on } \\
\text { infants (under 13) } \\
\text { Art 628: Aggravating Factors: } \\
\text { Min 5 yrs to max 25 yrs where } \\
\text { rape or sexual outrage leads } \\
\text { to pregnancy, disease, or } \\
\text { suicide. } \\
\text { Art 629/631: } \\
\text { indecent/homosexual acts } \\
\text { Criminal Code available at } \\
\text { www.lexadin.nl/wlg/legis/nofr } \\
\text { oeur/lxweeth.htm }\end{array}$ \\
\hline
\end{tabular}




\begin{tabular}{|c|c|c|c|c|}
\hline & Rape & Defilement & Sexual or indecent Assault & Relevant Statute \\
\hline Kenya & $\begin{array}{l}\text { Min. } 10 \text { yrs to max. life } \\
\text { imprisonment; Min. } 15 \text { yrs. to } \\
\text { max. life for gang rape; } \\
\text { attempt, min } 5 \text { yrs to max. life. } \\
\text { Note: Rape defined broadly- } \\
\text { any penetration by sexual } \\
\text { organ, gender neutral }\end{array}$ & $\begin{array}{l}\text { Min. life imprisonment if child } \\
\text { under 12; Min } 20 \text { yrs. if child } \\
\text { age 12-15; Min } 15 \text { yrs. if child } \\
\text { age 16-18; attempt, min. } 10 \\
\text { yrs. } \\
\text { Note: Defined as any } \\
\text { penetration. Applies to child } \\
\text { under } 18 \text { (gender neutral), not } \\
\text { spouse, w/ or w/o consent. } \\
\text { Note: minimums not } \\
\text { applicable if offender under } \\
18 \text { yrs. }\end{array}$ & $\begin{array}{l}\text { Penetrative sexual assault, } \\
\text { min. } 10 \text { yrs; indecent act (non- } \\
\text { penetrative) w/ child, min } 10 \\
\text { yrs to max. life; indecent act } \\
\text { w/ adult up to } 5 \text { yrs; Min } 10 \\
\text { yrs for sexual offence other } \\
\text { than rape/defilement by } \\
\text { person in position of trust or } \\
\text { authority (police, teacher, etc.) }\end{array}$ & $\begin{array}{l}\text { Sexual Offences Act (No } 3 \text { of } \\
\text { 2006) (as amended 2010): } \\
\text { S 3/4: rape } \\
\text { S 8/9: defilement } \\
\text { S 5: sexual assault } \\
\text { S 10: gang rape } \\
\text { S 11: indecent act w/child or } \\
\text { adult } \\
\text { S 24: sexual offence by person } \\
\text { in authority } \\
\text { Available at: } \\
\text { www.kenyalaw.org/kenyalaw/ } \\
\text { klr app/frames.php }\end{array}$ \\
\hline
\end{tabular}




\begin{tabular}{|c|c|c|c|c|}
\hline & Rape & Defilement & Sexual or indecent Assault & Relevant Statute \\
\hline Lesotho & $\begin{array}{l}\text { Min. } 10 \text { yrs for first offence, } \\
\text { min. } 15 \text { yrs where aggravating } \\
\text { factors: grievous bodily or } \\
\text { mental harm, victim under } 12 \\
\text { or exceptionally vulnerable, } \\
\text { offender STI infected and } \\
\text { aware, multiple perpetrators, } \\
\text { use of weapon, persistent } \\
\text { abuse of child. Increased } \\
\text { minimums for subsequent } \\
\text { convictions, } 20 \text { yrs to life. } \\
\text { (Lesser sentence may be } \\
\text { imposed for extenuating } \\
\text { circumstances) } \\
\text { Note: Term “rape" not used. } \\
\text { Offence is “unlawful sexual } \\
\text { acts," defined broadly- any } \\
\text { sexual act under "coercive } \\
\text { circumstances," gender } \\
\text { neutral. Allows for spousal } \\
\text { rape. } \\
\text { Note: minimums not } \\
\text { applicable to offenders under } \\
18 \text { yrs unless subsequent } \\
\text { offence }\end{array}$ & $\begin{array}{l}\text { Same as rape if coercive. Min. } \\
\text { sentence prescribed based on } \\
\text { prior convictions and other } \\
\text { aggravating factors. } \\
\text { Note: term "defilement" not } \\
\text { used. See unlawful sexual } \\
\text { acts. } \\
\text { Note: Applies to any child } \\
\text { under } 16 \text { (gender neutral). } \\
\text { Consent is defense if both } \\
\text { victim and offender 13-18 yrs. }\end{array}$ & $\begin{array}{l}\text { Min. } 8 \text { yrs and up, depending } \\
\text { on circumstances, prior } \\
\text { convictions and other } \\
\text { aggravating factors; min. } 15 \\
\text { yrs. for persistent sexual } \\
\text { abuse of child. }\end{array}$ & $\begin{array}{l}\text { Sexual Offences Act, 2003: } \\
\text { s 3: unlawful sexual acts } \\
\text { s 8: child molestation } \\
\text { s 9: persistent child sexual } \\
\text { abuse } \\
\text { s 31/32: penalties } \\
\text { Available at: } \\
\text { http://sgdatabase.unwomen.o } \\
\text { rg/uploads/Lesotho\%20- } \\
\text { \%20Sexual\%20Violence\%20A } \\
\text { ct\%202003.pdf }\end{array}$ \\
\hline
\end{tabular}




\begin{tabular}{|c|c|c|c|c|}
\hline & Rape & Defilement & Sexual or indecent Assault & Relevant Statute \\
\hline Namibia & $\begin{array}{l}\text { Min. } 5 \text { yrs for first conviction; } \\
\text { higher minimums where } \\
\text { aggravating factors - min. } 10 \\
\text { where violence used, min. } 15 \\
\text { where causes grievous harm, } \\
\text { victim under } 13 \text { or } \\
\text { exceptionally vulnerable, } \\
\text { victim under } 18 \text { and offender } \\
\text { in position of trust, multiple } \\
\text { perpetrators, use of weapon, } \\
\text { or offender infected with } \\
\text { serious STI and aware. } \\
\text { Minimums increase to 10-45 } \\
\text { yrs. for repeat offenders. } \\
\text { Lesser sentence may be } \\
\text { imposed where court finds } \\
\text { “substantial and compelling } \\
\text { circumstances." } \\
\text { Note: rape defined broadly - } \\
\text { any penetration under } \\
\text { "coercive circumstances," } \\
\text { gender neutral } \\
\text { Note: minimums not } \\
\text { applicable to offenders under } \\
18 \text { yrs. }\end{array}$ & $\begin{array}{l}\text { Same as rape (min. 5-45 yrs) if } \\
\text { coercive circumstances; Fine } \\
\text { and up to } 10 \text { yrs or both for } \\
\text { (non-coercive) sexual acts or } \\
\text { attempted acts with youths (no } \\
\text { min.). } \\
\text { Note: Term "defilement" not } \\
\text { used. "Sexual act" defined as } \\
\text { per Combatting of Rape Act. } \\
\text { Applies to child under 16, } \\
\text { where offender is more than } 3 \\
\text { yrs older and not married to } \\
\text { victim. }\end{array}$ & $\begin{array}{l}\text { Penetrative forms of sexual } \\
\text { assault incl. oral, now covered } \\
\text { by rape; no minimum for other } \\
\text { forms of indecent assault } \\
\text { under common law; (non- } \\
\text { coercive) sexual and indecent } \\
\text { acts w/ child under 16, fine } \\
\text { and up to 10yrs. }\end{array}$ & 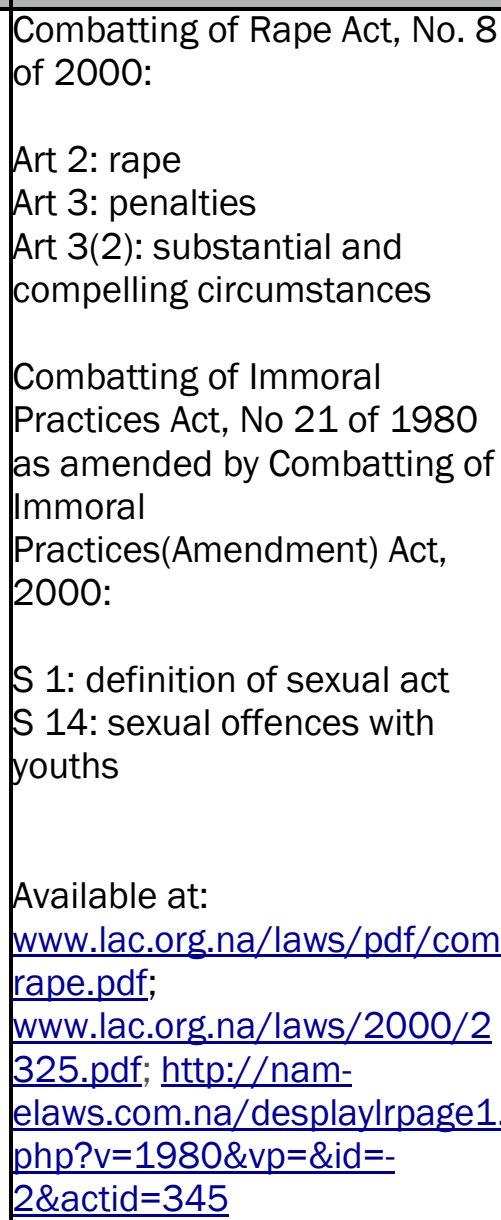 \\
\hline
\end{tabular}




\begin{tabular}{|c|c|c|c|c|}
\hline & Rape & Defilement & Sexual or indecent Assault & Relevant Statute \\
\hline Malawi & $\begin{array}{l}\text { Max penalty death or life } \\
\text { imprisonment w/ or w/o } \\
\text { corporal punishment (no } \\
\text { mins); attempt, up to life. } \\
\text { Note: uses common law } \\
\text { definition of rape (females } \\
\text { only) }\end{array}$ & $\begin{array}{l}\text { Max life imprisonment w/ or } \\
\text { w/o corporal punishment; } \\
\text { attempt, max } 14 \text { yrs. } \\
\text { Note: Applies only to girls } \\
\text { under 13; (rape may be } \\
\text { charged for older girls if no } \\
\text { consent). }\end{array}$ & $\begin{array}{l}\text { Max } 14 \text { yrs w/ or w/o corporal } \\
\text { punishment (females); Max } 7 \\
\text { yrs w/ or w/o corporal } \\
\text { punishment if boy under } 14 . \\
\text { See also sodomy (up to } 15 \\
\text { yrs). } \\
\text { Note: Consent is defence if girl } \\
\text { over } 13\end{array}$ & $\begin{array}{l}\text { Penal Code (Ch. 7:01) } \\
\text { S 132/3: rape } \\
\text { S 138: defilement } \\
\text { S 137: indecent assault } \\
\text { (females) } \\
\text { S 155: indecent assault (boys) } \\
\text { S 153: sodomy } \\
\text { S 157: incest } \\
\\
\text { Available at: } \\
\text { www.malawilii.org/mw/legislat } \\
\text { ion/consolidated-act/701 }\end{array}$ \\
\hline
\end{tabular}




\begin{tabular}{|c|c|c|c|c|}
\hline & Rape & Defilement & Sexual or indecent Assault & Relevant Statute \\
\hline Rwanda & $\begin{array}{l}\text { Min } 10 \text { yrs to max } 15 \text { yrs; Min } \\
15 \text { to max } 20 \text { if causes bodily } \\
\text { or mental illness; life } \\
\text { imprisonment if causes death } \\
\text { or terminal illness. Statute } \\
\text { also mandates payment of } \\
\text { victim's medical fees; right to } \\
\text { claim for damages. Spousal } \\
\text { rape recognized as offence, } \\
\text { but reduced penalties: Min } 6 \\
\text { mo to } 2 \text { yrs imprisonment for } \\
\text { spousal rape. } \\
\text { Note: rape defined as sexual } \\
\text { intercourse without consent }\end{array}$ & $\begin{array}{l}\text { Min. } 20 \text { yrs to max } 25 \text { and fine } \\
\text { if child 14-18; min. life if under } \\
\text { 14. Aggravating factors } \\
\text { include HIV and abuse of } \\
\text { power/relationship: death } \\
\text { penalty if child dies or is } \\
\text { infected with incurable } \\
\text { disease, life imprisonment and } \\
\text { fine if offender is parent, } \\
\text { guardian, teacher, religious } \\
\text { leader, etc. } \\
\text { Note: Child is person under } 18 \\
\text { (gender neutral). Term } \\
\text { "defilement" not used. "Any } \\
\text { sexual relations" with child } \\
\text { defined as "rape." (art 33). }\end{array}$ & $\begin{array}{l}\text { Min } 2 \text { yrs to max } 5 \text { plus fine } \\
\text { for "indecent acts." Min } 1 \text { yr } \\
\text { for "dehumanizing acts" } \\
\text { against child. See also child } \\
\text { rape, min. } 20 \text { yrs. for "sexual } \\
\text { relations" with child. Min } 10 \\
\text { yrs to max } 15 \text { yrs plus fine for } \\
\text { "sexual violence" against } \\
\text { elderly or handicapped } \\
\text { person. See also sexual } \\
\text { harassment and sexual } \\
\text { slavery provisions. }\end{array}$ & $\begin{array}{l}\text { Law No.59/2008 on } \\
\text { Prevention and Punishment of } \\
\text { Gender Based Violence: } \\
\text { Art 2: definitions } \\
\text { Art 16: penalty for rape } \\
\text { Art 5/19: conjugal rape/ } \\
\text { penalty } \\
\text { Art 31: indecent acts } \\
\text { Art 32/33: sexual violence } \\
\text { against elderly or handicapped } \\
\text { person } \\
\text { Art 38: damages } \\
\text { Law 27/2001 Relating to the } \\
\text { Rights and Protection of the } \\
\text { Child Against Violence } \\
\text { Art 33-37: rape and use of } \\
\text { child for dehumanizing acts } \\
\text { Available at: } \\
\text { www.unhcr.org/refworld/pdfid } \\
44 a 3 f 88812 . p d f ; \\
\text { www.amategeko.net/index.ph } \\
\text { p?Parent ID=7726 }\end{array}$ \\
\hline
\end{tabular}




\begin{tabular}{|c|c|c|c|c|}
\hline & Rape & Defilement & Sexual or indecent Assault & Relevant Statute \\
\hline South Africa & $\begin{array}{l}\text { Min. life imprisonment for } \\
\text { Schedule 2, Part I cases } \\
\text { including: rape of girl under } \\
\text { 16; rape causing grievous } \\
\text { bodily harm; rape under } \\
\text { specific aggravated } \\
\text { circumstances (multiple rapes } \\
\text { or perpetrators, HIV- infected } \\
\text { perpetrator, prior convictions); } \\
\text { rape of mentally or physically } \\
\text { disabled victim. Min } 10 \text { yrs all } \\
\text { other rapes (Schedule 2, Part } \\
\text { III) or min.15-20 yr. if prior } \\
\text { convictions. Lesser sentence } \\
\text { may be imposed where court } \\
\text { finds "substantial and } \\
\text { compelling circumstances." } \\
\text { Note: rape defined broadly - } \\
\text { any penetration, gender } \\
\text { neutral. } \\
\text { Note: minimums not } \\
\text { applicable to offenders under } \\
16 \text { yrs. }\end{array}$ & $\begin{array}{l}\text { Same as rape if coercive or } \\
\text { child under } 12 . \\
\text { No min. for consensual sexual } \\
\text { penetration with child } 12-16 \\
\text { (statutory rape). } \\
\text { Note: gender neutral offence; } \\
\text { term "defilement" not used. }\end{array}$ & $\begin{array}{l}\text { Min. } 10 \text { yrs for indecent } \\
\text { assault of child under } 16 \\
\text { w/bodily harm (Schedule } 2, \\
\text { Part III); min } 15-20 \text { yrs for } \\
\text { subsequent offences. Lesser } \\
\text { sentence may be imposed } \\
\text { where court finds "substantial } \\
\text { and compelling } \\
\text { circumstances." No minimum } \\
\text { for sexual assault of adults, } \\
\text { except where constitutes rape. } \\
\text { Note: All penetrative forms of } \\
\text { sexual assault now defined as } \\
\text { rape. }\end{array}$ & $\begin{array}{l}\text { Criminal Law Amendment Act } \\
\text { 1997; as revised by Criminal } \\
\text { Law (Sentencing) Amendment } \\
\text { Act No. } 38 \text { of } 2007 . \\
\text { S 51(1)-(3): minimum } \\
\text { sentences for serious offences } \\
\text { See also: Criminal Law (Sexual } \\
\text { Offences) Amendment Act } \\
2007 \\
\text { S 2: rape } \\
\text { S 5: sexual assault } \\
\text { S 15: statutory rape } \\
\text { (consensual) } \\
\text { S 16: statutory sexual assault } \\
\text { (consensual) } \\
\text { Available at: } \\
\text { www.saflii.org/za/legis/num a } \\
\text { ct/claa1997205.pdf; } \\
\text { www.saflii.org/za/legis/num a } \\
\text { ct/claa2007305.pdf; } \\
\text { www.info.gov.za/view/Downlo } \\
\text { adFileAction?id=77866 }\end{array}$ \\
\hline
\end{tabular}




\begin{tabular}{|c|c|c|c|c|}
\hline & Rape & Defilement & Sexual or indecent Assault & Relevant Statute \\
\hline Tanzania & $\begin{array}{l}\text { Min. } 30 \text { yrs w/ corporal } \\
\text { punishment and fine plus } \\
\text { compensation to victim; Min. } \\
\text { life for gang rape; Min. life for } \\
\text { rape of girl under age 10; } \\
\text { Attempt, min } 30 \text { yrs to max } \\
\text { life, or min } 10 \text { yrs. in case of } \\
\text { false representations. Lower } \\
\text { penalties for offenders under } \\
18 . \\
\text { Note: Rape - modified } \\
\text { common law definition } \\
\text { (females only); no spousal } \\
\text { rape unless separated. }\end{array}$ & $\begin{array}{l}\text { Min } 30 \text { yrs. w/corporal } \\
\text { punishment and fine plus } \\
\text { compensation to victim. } \\
\text { Defilement of wife if under age } \\
15, \text { up to } 10 \text { yrs (no min). } \\
\text { Note: Same offence and } \\
\text { penalties as rape; term } \\
\text { "defilement" not used. offence } \\
\text { applies to sexual intercourse } \\
\text { with girl under } 18, \text { w/ or w/o } \\
\text { consent, unless spouse and } \\
\text { over } 15 \text { yrs old. }\end{array}$ & $\begin{array}{l}\text { Min. } 15 \text { to max } 30 \text { w/ corporal } \\
\text { punishment and } \\
\text { compensation for "grave } \\
\text { sexual abuse;" Min. } 20 \text { to max } \\
30 \text { if victim under 15; Min. } 1 \\
\text { yrs or fine for gross indecency } \\
\text { if adult; min } 10 \text { yrs w/ corporal } \\
\text { punishment and } \\
\text { compensation if victim under } \\
18 \text { or student, by adult. } \\
\text { Indecent assault of boy under } \\
14, \text { up to life. Min 30yrs for } \\
\text { sodomy (w/ or w/o consent); } \\
\text { attempt min.20; min life if with } \\
\text { child under } 10 . \\
\text { Note: grave sexual abuse } \\
\text { (penetration w/o consent) and } \\
\text { gross indecency are gender } \\
\text { neutral offences, but sodomy } \\
\text { laws still in place. }\end{array}$ & $\begin{array}{l}\text { Penal Code (Ch 16) as } \\
\text { amended by the Sexual } \\
\text { Offences Special Provisions } \\
\text { Act of 1998. } \\
\text { S 130/131: rape } \\
\text { S 130(2)(e): sexual } \\
\text { intercourse with girl under } 18 \\
\text { S 138(1): defilement of wife } \\
\text { under age } 15 \\
\text { S 138C: grave sexual abuse } \\
\text { S 138A: gross indecency } \\
\text { S 130: rape by person in } \\
\text { authority } \\
\text { S } 154-6: \text { sodomy/indecent } \\
\text { assault of boy under 14 } \\
\text { Minimum Sentences Act, } \\
\text { 1972 (as amended), S 5/6 } \\
\text { Available at: } \\
\text { www.Irct.go.tz/download/upda } \\
\text { ted-acts-tanzania/PENAL.pdf; } \\
\text { www.unhcr.org/refworld/docid } \\
\text { 3ae6b5098.html; } \\
\text { www.Irct.go.tz/download/upda } \\
\text { ted-acts- } \\
\text { tanzania/MINIMUM.pdf }\end{array}$ \\
\hline
\end{tabular}




\begin{tabular}{|c|c|c|c|c|}
\hline & Rape & Defilement & Sexual or indecent Assault & Relevant Statute \\
\hline Uganda & $\begin{array}{l}\text { Up to death (no minimum); } \\
\text { attempt, up to life w/ or w/o } \\
\text { corporal punishment } \\
\text { Note: Rape - common law } \\
\text { definition (females only) }\end{array}$ & $\begin{array}{l}\text { Up to life; attempt, up to } 18 \\
\text { yrs; up to death penalty for } \\
\text { aggravated defilement; up to } \\
\text { life for attempt (no } \\
\text { minimums). Aggravating } \\
\text { circumstances include: age of } \\
\text { victim (under 14); perpetrator } \\
\text { HIV+ and aware; abuse of } \\
\text { power or relationship (incl } \\
\text { parent/guardian); repeat } \\
\text { offender. Different penalties } \\
\text { apply where perpetrator and } \\
\text { victim both under } 18 \text { (See } \\
\text { Children's Act). } \\
\text { Note: Definition of } \\
\text { "defilement" amended in } \\
\text { 2007 to include (penetrative) } \\
\text { sexual act with "any person" } \\
\text { under } 18 \text { (gender neutral), w/ } \\
\text { or w/o consent. } \\
\text { Note: Statute provides for } \\
\text { payment of compensation in } \\
\text { addition to any other penalty; } \\
\text { relevant factors include extent } \\
\text { of harm to victim; degree of } \\
\text { force used; expenses incurred. }\end{array}$ & $\begin{array}{l}\text { Up to } 14 \text { yrs w/ or w/o } \\
\text { corporal punishment; up to } 14 \\
\text { yrs w/ or w/o corporal } \\
\text { punishment for indecent } \\
\text { assault on boys (under 18). } \\
\\
\text { Note: consent not a defence } \\
\text { for girls under } 18 .\end{array}$ & $\begin{array}{l}\text { Penal Code Act } 1950 \text { (Ch. } \\
\text { 120), as amended by Penal } \\
\text { Code (Amendment) Act of } \\
2007 . \\
\text { S 124: rape } \\
\text { S 129: defilement } \\
\text { S 129(3): aggravated } \\
\text { defilement } \\
\text { S 128/147: indecent assault } \\
\text { Available at: www.ulii.org; } \\
\text { www.icrc.org/ihl- } \\
\text { nat.nsf/a24d1cf3344e99934 } \\
125673 e 00508142 / 158 b b d \\
\text { bd1f43d1ebc12576f5003f73 } \\
\text { 81!OpenDocument }\end{array}$ \\
\hline
\end{tabular}




\begin{tabular}{|c|c|c|c|c|}
\hline & Rape & Defilement & Sexual or indecent Assault & Relevant Statute \\
\hline Zambia & $\begin{array}{l}\text { Min. } 15 \text { yrs, up to life; Min. } 14 \\
\text { yrs for attempt. } \\
\text { Note: rape - common law } \\
\text { definition (females only) }\end{array}$ & $\begin{array}{l}\text { Min. } 15 \text { yrs, up to life; Min } 14 \\
\text { yrs to max } 20 \text { yrs for attempt. } \\
\text { Min. does not apply to } \\
\text { perpetrators under } 16 \text { yrs. } \\
\text { Note: Applies to any child } \\
\text { under 16, w/ or w/o consent } \\
\text { (gender neutral). } \\
\text { Note: "prescribing" defilement } \\
\text { of child as cure for disease is } \\
\text { crim. offence, with min. } \\
\text { sentence } 15 \text { yrs., max. life. }\end{array}$ & $\begin{array}{l}\text { Min. } 15 \text { yrs to max } 20 . \\
\text { Note: “Indecent assault" not } \\
\text { defined; applies to assault of } \\
\text { "child or other person" (gender } \\
\text { neutral); Consent not a } \\
\text { defence where victim is a child } \\
\text { (under 16). } \\
\text { Note: Sexual harassment of } \\
\text { child, min. } 3 \text { yrs to max.15 yrs. }\end{array}$ & $\begin{array}{l}\text { Penal Code (Vol } 7 \text { Laws of } \\
\text { Zambia, Chapt } 87 \text { ) as } \\
\text { amended by: } \\
\text { Penal Code (Amendment) Act } \\
\text { No } 15 \text { of 2005; } \\
\text { S } 137(1) \text { : indecent assault } \\
\text { S } 137 \text { A: sexual harassment of } \\
\text { child } \\
\text { S 138: defilement } \\
\text { Penal Code (Amendment) Act } \\
\text { No } 2 \text { of 2011; } \\
\text { S 133: rape } \\
\text { Available at: } \\
\text { www.parliament.gov.zm/downl } \\
\text { oads/VOLUME\%207.pdf;www. } \\
\text { parliament.gov.zm/index.php? } \\
\text { option=com docman\&task=d } \\
\text { oc view\&gid=849 }\end{array}$ \\
\hline
\end{tabular}




\begin{tabular}{|c|c|c|c|c|}
\hline & Rape & Defilement & Sexual or indecent Assault & Relevant Statute \\
\hline Zimbabwe & $\begin{array}{l}\text { Up to life imprisonment for } \\
\text { rape and attempted rape. } \\
\text { No minimum but code } \\
\text { specifies factors to be taken } \\
\text { into account in sentencing: } \\
\text { age of victim; degree of force } \\
\text { or violence used; extent of } \\
\text { physical or psychic injury to } \\
\text { victim; number of } \\
\text { perpetrators; age of } \\
\text { perpetrator; use of weapon; } \\
\text { relationship of victim to } \\
\text { perpetrator/abuse of power; } \\
\text { HIV infection. } \\
\text { Note: Rape includes sexual } \\
\text { intercourse with female only, } \\
\text { but same penalties apply for } \\
\text { aggravated (penetrative) } \\
\text { assault (male or female } \\
\text { victim). Spousal rape } \\
\text { recognized as offence. }\end{array}$ & $\begin{array}{l}\text { Same as rape if under } 16 \text { and } \\
\text { non-consensual; Up to } 10 \text { yrs } \\
\text { and/or fine for sexual } \\
\text { intercourse w/consent. } \\
\text { Note: term "defilement" not } \\
\text { used. }\end{array}$ & $\begin{array}{l}\text { Aggravated sexual assault } \\
\text { (penetrative) of male or } \\
\text { female, same as rape; up to } 2 \\
\text { yrs and/or fine for non- } \\
\text { penetrative assault; up to } 10 \\
\text { yrs and/or fine for indecent } \\
\text { act with young person. }\end{array}$ & $\begin{array}{l}\text { Criminal Law (Codification and } \\
\text { Reform) Act } 2004 \text { (effective } \\
\text { 7/2006) } \\
\text { S 65: rape } \\
\text { S 70: sexual acts with young } \\
\text { persons } \\
\text { S 66: aggravated indecent } \\
\text { assault } \\
\text { S 67: indecent assault } \\
\text { S 68: spousal rape } \\
\text { S 75: incest w/o consent } \\
\\
\text { Available at: } \\
\text { www.kubatana.net/html/archi } \\
\text { ve/legisl/050603crimlaw.asp } \\
\text { ?orgcode=par001\&year=0\&ra } \\
\text { nge start=1 }\end{array}$ \\
\hline
\end{tabular}


1 The use of the term 'survivor,' rather than 'victim' for those who have experienced rape is increasingly common. Nonetheless, the use of the term 'victim,' for some, is an acknowledgement of the long-term work that coping with the violent crime of rape requires. In this report, the term 'victim' is used because of the legal (as opposed to medical management, for example) context in which the study was conducted. For more information on the use of the term 'survivor' versus 'victim,' see Campbell, R., Mental Health Services for Rape Survivors Current Issues in Therapeutic Practice. Report commissioned by Violence against Women Online Resources, 2001. Available from: http://www.mincava. umn.edu/documents/commissioned/campbell/campbell.html. See also Vetten L, Jewkes R, Sigsworth R, Christofides N, Loots L, Dunseith O., Tracking Justice: The attrition of rape cases through the criminal justice system in Gauteng.Johannesburg. Tshwaranang Legal Advocacy Centre, the South African Medical Research Council and the Centre for the Study of Violence and Reconciliation. Available from: http://www.tlac.org.za/wp-content/uploads/2012/01/TrackingJustice.pdf.

2 The offense of "defilement" generally refers to unlawful sexual intercourse with a girl child, with or without her consent. The age of the child varies from statute to statute, and in some cases has been redefined to include boys.

${ }^{3}$ O'Donovan, M. and Redpath, J., 2006. The Impact of Minimum Sentencing in South Africa, Open Society Foundation for South Africa, Report 2.

4 Ibid .

${ }^{5}$ See, Thompson, J., Rape Sentencing Study Part II: Review of Literature on Minimum Sentencing, Population Council, 2012.

${ }^{6}$ See, for example, South Africa, Namibia, Kenya, Lesotho and Botswana, where forms of sexual penetration other than intercourse may constitute rape, and/or where males as well as females may be victims of rape and/or defilement.

${ }^{7}$ See, for example, South Africa, Namibia, and Zimbabwe.

${ }^{8}$ See, e.g. Muthoga, R. \& Bowman, “A brief survey of sentencing laws and its practice in Kenya,” Fed. Sent. R. 22, 2010.

${ }^{9}$ See, e.g. Muthoga, R., 2010.

10 See Sexual Offences Act 2006, Laws of Kenya, sect. 33(b).

11 Muthoga, R., 2010.

12 Ibid.

13 Ibid.

14 See Criminal Law (Sentencing) Amendment Act 2007.

${ }^{15}$ In Lesotho, minimums are prescribed for "unlawful sexual acts," rather than rape, per se. See Sexual Offences Act, 2003.

16 S v Malgas 20011 SAC R 469 (SCA), confirmed by the Constitutional Court in S v Dodo 20011 SACR 594 (CC) and adopted by the Namibian courts in S. v. Lopez 2003 NR 162 (HC).

${ }^{17}$ See, e.g. Terblanche, S.S. and Roberts, J., Sentencing in South Africa: Lacking in principle but delivering justice? 18 S. Afr. Crim Just. 187 (2005). See also footnote 41, supra.

18 See Criminal Law (Sentencing) Amendment Act (2007), section 51(3). According to the Act, the following factors "may not constitute substantial and compelling circumstances justifying the imposition of a lesser sentence in a case of rape: (i) The complainant's previous sexual history; (ii) an apparent lack of physical injury to the complainant; (iii) an 
accused person's cultural or religious beliefs about rape; or (iv) any relationship between the accused person and the complainant." Research suggests, however, that judges continue to use these factors in sentencing. See e.g., Vetton, L. and van Jaarsveld, The (mis)measure of harm: an analysis of rape sentences handed down in the regional high courts of Gauteng Province, 2008. Hassan, L. Sentencing under the Combating of Rape Act, 2000: the misapplication of judicial discretion, Nam. Law J., Vol 3, Issue 1, Jan 2011.

${ }^{19}$ See, e.g. definition of rape under section 2 of Namibia's Combatting of Rape Act 2000, substituting acts committed under "coercive circumstances" for the previous requirement of non-consent.

20 Sexual Offences Act 2001

${ }^{21}$ Criminal Law (Codification and Reform) Act, 2004 (2006).

22 Criminal Code of the Federal Democratic Republic of Ethiopia, 2004 (2005).

23 The Prevention and Punishment of Gender-Based Violence Act, No. 59 of 2008 (2009).

24 Sexual Offences Act, No 3 of 2006 (revised 2010) (Kenya); Sexual Offences Act 2003 (Lesotho); Combating of Rape Act, No 8 of 2000 (Namibia) in combination with the Combating of Immoral Practices (Amendment) Act 2000

(Namibia); Criminal Law (Sexual Offences) Amendment Act 2007 (South Africa); Sexual Offences Special Provisions Act (SOSPA), 1998 (Tanzania).

25 Tanzania also recognizes spousal rape but only if the couple is separated.

${ }^{26}$ Criminal Law Amendment Act, 1997, S 51.

${ }^{27}$ Law relating to the rights and protection of the child against violence, 2001, art. 33-37.

${ }^{28}$ Penal Code (Amendment) Act, No. 5 of 1998.

${ }^{29}$ Ibid, at section 2.

${ }^{30}$ Penal Code (Amendment) Act, No. 15 of 2005.

${ }^{31}$ Penal Code (Amendment) Act, No. 2 of 2011.

32 When Malawi enacted its current sentencing structure for rape and defilement (maximum life sentence) could not be determined from the desk review of the Penal Code.

33 Penal Code (Amendment Act) 2006 (2007)

34 Penal Code (Amendment) Act 2005, section 138; Penal Code (Amendment) Act 2011 Sections 3(3) and 4.

${ }^{35}$ Note that Tanzania has enacted a Minimum Sentencing Act which appears to grant courts wide discretion in the case of first offenders. While Section 5 states that the courts "shall sentence" persons convicted of sexual offences to the minimum sentences prescribed in the amended penal code, Section 6 allows the court to "proceed ... as if this Act had not been enacted" in the case of first offenders, if, given all the circumstances of the case, it would be "just and equitable to do so."

36 Penal Code (Amendment) Act, 1998, sections 142, 147.

37 Sexual Offences Act 2003, section 8.

38 Ibid, Section 26(1).

${ }^{39}$ Criminal Code of the Federal Democratic Republic of Ethiopia, 2004 Art 620 et seq.

${ }^{40}$ In addition to the sentences provided in the criminal code for specific sexual offences, Ethiopia also sets out more general sentencing guidelines in its criminal code. These include a list of both mitigating and aggravating sentences, which presumably apply in all criminal cases. It is not clear on the face of the statute whether courts may impose a sentence lower than the statutory minimum where mitigating factors are found to be present.

41 The 1997 Act does not define or provide guidance on the term "substantial and compelling circumstances," and, as a 
result, a substantial body of case law has developed in South Africa as to the practical application of the test. In general, the court is required to take into account all relevant aggravating and mitigating factors in determining whether substantial and compelling circumstances are present. This results in a situation where, despite the substantial body of case law, sentencing outcomes "remain largely unpredictable and dependent on the value judgement of the court. "See, SS Terblanche, 18 S. Afr. J. Crim. Just. 187 (2005).

${ }^{42}$ For more information and critique on this issue, see discussion in Thompson, J., Rape Sentencing Study Part II: Review of Literature on Minimum Sentencing, Population Council, 2012. See also, De Smet, A. and Hubbard, D., "Substantial and Compelling Circumstances" in Rape Cases, Legal Assistance Center, Windhoek, 2009; Kubista, N., "Substantial and compelling circumstances: Sentencing of rapists under the mandatory sentencing scheme, $18 \mathrm{~S}$. Afr. J. Crim. Just 77 (2005); Baehr, K. Mandatory Minimums Making Minimal Difference: Ten Years of Sentencing Sex Offenders in South Africa, 20 Yale Journal of Law and Feminism 213 (2008).

${ }^{43}$ Criminal Code 2004, section 65(1) and 66.

${ }^{44}$ This is not true across countries, however. Many countries (such as Malawi, Ethiopia, Rwanda, Uganda, Tanzania, and Zambia) have retained the more narrow common or civil law definition of rape, although Zambia has made the offence gender-neutral.

${ }^{45}$ For a detailed analysis of sentencing literature, see Thompson, J., Rape Sentencing Study Part II: Review of Literature on Minimum Sentencing, Population Council, 2012.

${ }^{46}$ Ibid.

${ }^{47}$ Ibid.

48 Ibid.

${ }^{49} \mathrm{Ibid}$. See also: Terblanche, S.S. and Roberts, J., Sentencing in South Africa: Lacking in principle but delivering justice? 18 S. Afr. Crim Just. 187 (2005) and Baehr, K. Mandatory Minimums Making Minimal Difference: Ten Years of Sentencing Sex Offenders in South Africa, 20 Yale Journal of Law and Feminism 213 (2008).

${ }^{50}$ O’Donovan, M. and Redpath, J., 2006. The Impact of Minimum Sentencing in South Africa, Open Society

Foundation for South Africa, Report 2. Note that South Africa has since expanded the jurisdiction of the regional court to reduce the number of split procedures.

${ }^{51}$ Baehr, K. Mandatory Minimums Making Minimal Difference: Ten Years of Sentencing Sex Offenders in South Africa, ${ }^{20}$ Yale Journal of Law and Feminism 213 (2008). In addition to looking at sentencing, countries must attempt to deal with the causes of sexual violence, including social and cultural attitudes about women and rape. They must also strengthen the legal framework around sexual offences and develop comprehensive strategies and programs to strengthen the criminal justice system as a whole. 